DOI: $10.2478 / \mathrm{v} 10025-010-0009-6$

JOURNAL OF WATER

AND LAND DEVELOPMENT

J. Water Land Dev. No. 13b, 2009: 125-135

\title{
The use of hydrogel in afforestation of postindustrial areas
}

\author{
Wiestaw PTACH ${ }^{1)}$ Andrzej BOCZON'²), Michat WRÓBEL ${ }^{2)}$
}

\author{
1) Warsaw University of Life Sciences, Faculty of Engineering and Environmental Science, ul. No- \\ woursynowska 166, 02-787 Warsaw, Poland; e-mail: wieslaw_ptach@sggw.pl \\ 2) Forest Research Institute, Sękocin Stary, ul. Braci Leśnej 3, 05-090 Raszyn, Poland; e-mail: \\ a.boczon@ibles.waw.pl,m.wrobel@ibles.waw.pl
}

\begin{abstract}
Some areas intended for afforestation are characterised by a lack of moisture and mineral nutrients. One of the approaches to improve water retention capacity of soils is the use of hydrogels (polymer soil conditioners). The presented experiment was performed with 4 different methods of hydrogel applications and control in a post-industrial area - a dumping ground of the Brown Coal Mine Bełchatów (Forest District Administration Bełchatów). The Aquaterra product (pure hydrogel) and hydrogel with nutrients (TerraVit) produced by Terra-Gubin company were used in all experiments. From 292 to 306 one-year old seedlings of Pinus sylvestris L. of an average height of 80-101 $\mathrm{mm}$ were planted in each plot. The influence of hydrogel application method on successful afforestation and growth of seedling was analyzed after the first vegetation year. Maximum number of survived seedlings (93.3\%) was observed for hydrogel applied through roots coating, minimum (72.4\%) for hydrogel with fertilizers applied under plants. Results obtained for pure hydrogel surface application $(89.1 \%)$ and pure hydrogel applied under plants $(85.3 \%)$ can be compared with results from control plot $(89.7 \%)$. Mean heights of surviving seedlings were similar $(128-130 \mathrm{~mm})$ for root coating, and both methods of hydrogel application under plants, in contrast with surficial hydrogel application $(117 \mathrm{~mm})$ and control where they were minimal $(111 \mathrm{~mm})$. Mean height increments in surviving seedlings were minimum in control plot $(31 \mathrm{~mm})$, and similar $(38-40 \mathrm{~mm})$ for root coating and surface application. The best results of height increments $(47 \mathrm{~mm})$ were obtained when hydrogel mixed with fertiliser was applied under plants. To sum up, in view of plant survival the best method of polymer soil conditioner (hydrogel) application was root coating; this method gave also satisfactory increments of plant height.
\end{abstract}

Key words: afforestation, hydrogels, Pinus sylvestris

\section{INTRODUCTION}

Waste heaps and dumping grounds are inseparable elements accompanying coal mining and processing. Particularly visible in the landscape are waste heaps in the surrounding of brown coal mines whose volume exceeds billion $\mathrm{m}^{3}$ (Tab. 1). 
Table 1. Parameters of selected above-ground external waste heaps (UBERMAN, OSTRĘGA, 2004)

\begin{tabular}{l|c|c|c}
\hline \multirow{2}{*}{ Mine } & \multicolumn{3}{|c}{ Parameter } \\
\cline { 2 - 4 } & area, ha & height, $\mathrm{m}$ & volume, million $\mathrm{m}^{3}$ \\
\hline Brown Coal Mine „Bełchatów” & 1480 & 195 & 1350 \\
Brown Coal Mine „Turów” & 2175 & 245 & 1470 \\
Sulphur Mine „Machów” & 880 & 60 & 184 \\
Coal Mine Rydułtowy & 37 & 140 & 13.3 \\
\hline
\end{tabular}

More and more attention has recently been paid to the way of restoring grounds degraded by industry including those devastated by exploitation of mineral resources (OSTRĘGA, 2004). Abandoned mining activity is often followed by spontaneous succession of natural habitats. The process is named renaturisation (natural succession) and is defined as spontaneous invasion of plant and animal species onto degraded grounds (WITT, 2006). The process is often insufficient to restore primary environmental status which means a necessity of carrying restoration works in agreement with present legal regulations. The direction of restoration means the range and methods of restoration in view of future land management. Full systematics of management directions determining the range and methods of restoration works is complex and results from many factors and from advisability criteria. Most authors of classifications cited by OSTRĘGA (2004) consider afforestation as one of the main and most frequently used restoration method.

Soils of post-mining areas are artificial products of human activity being at the initial stage of development which clearly affects their physical and water properties (SZAFRAŃSKI et al., 2001). They are characterised by the rainfall-retention water management (SZAFRAŃSKI and STACHOWSKI, 1998). In such soils almost all plant demands for water are covered by atmospheric precipitation since the ground water table depth is practically of no importance for plants (SZAFRAŃSKI and STACHOWSKI, 1998). Soil moisture in post-mining grounds depends mainly on rainfalls and on retention capacity of newly formed soil (SZAFRAŃSKI and STACHOWSKI, 1997; SZAFRAŃSKI et al., 2001), which together with frequent nutrient deficiency creates unfavourable conditions for plant growth.

One of relatively new methods of improving water budget in soils is the use of hydrogels - synthetic polymer organic substances called soil conditioners. These substances retain water increasing thus water and nutrient retention capacity of soils. They prevent soils from crusting over and increase their infiltration abilities. These properties of hydrogels are used to improve water budget of sandy soils through elongation of their drying after rainfalls. The studies on hydrogels were carried out mainly in field and garden crops in soils of small retention capacity (SILBERBUSCH et al., 1993a; 1993b; PIERZGALSKI and PTACH, 1999). One of the first experiments on their use in forestry was performed in Arizona, USA where the success of sprouting seeds of Pinus ponderoza and survival of pine seedlings were studied in the years 
1972-1973 (RIETVELD, 1976). Studies on the use of synthetic soil conditioners to improve retention capacity of sandy soil as a substratum for Pinus halepensis grown in laboratory conditions were carried out by HUTTERMANN et al. (1999). Results of these studied demonstrated marked increase of moisture in the hydrogel treated rhisosphere obtained during drought as compared with control samples. The efficiency of using hydrogels for restoration of dumping grounds in potash mine planted with poplar Populus deltoides and the Russian olive Elaeagnus angustifolia was analysed in Germany (KAHL et al., 2000). There have been no studies on using synthetic soil conditioners in the restoration of post-industrial grounds in Poland. Potential efficiency of hydrogel application and the importance of afforestation methods in land management justifies undertaking such studies. Results of observations and field studies on the effect of hydrogel application on the effectiveness of afforestation of post-industrial areas are presented in this paper.

\section{METHODS}

The aim of performed studies was to estimate the effectiveness and conditions of hydrogel application in areas difficult for afforestation. Of particular importance was to find the effect of hydrogels on planting success and the growth of seedlings in the first year after planting. Field experiment was performed in the area of external waste heap of the Brown Coal Mine "Bełchatów" (Fig. 1) in soil of the grain size structure of light loamy sand.

Five neighbouring study plots of an area from 313 to $323 \mathrm{~m}^{2}$ (Fig. 2) were selected to perform five experimental variants. The variants were differentiated in the type and method of application of soil conditioner and included:

BH1 - control plot without hydrogel,

$\mathrm{BH} 2$ - hydrogel mechanically mixed with the surface soil layer $5 \mathrm{~cm}$ thick in a $0.5 \mathrm{~m}$ wide belt to obtain hydrogel concentration of c. $0.5 \%$ by weight,

$\mathrm{BH} 3$ - hydrogel spilled under every plant at a dose of $2.5 \mathrm{~g}$ per seedling,

BH4 - soil conditioner used in a form of water gel used to immerse plants' roots just before their planting,

BH5 - a mixture of hydrogel and fertiliser applied under every plant at a dose of

5 g per seedling.

The seedlings of the Scots pine (Pinus sylvestris L.) from forest nursery of the Forestry District Bełchatów were planted in 10 rows of 30 plants in every previously prepared study plots. Planting (bar-slit method) was performed in May 2007. Two soil conditioners from one producer were used in experiments:

TerraVit - containing latticed potassium polyacrylate (20\%), macro- and micronutrients $(55 \%)$, correction fertilisers $(1 \%)$ and bentonite as a structural additive $(24 \%)$;

AquaTerra - in a pure form without additives. 


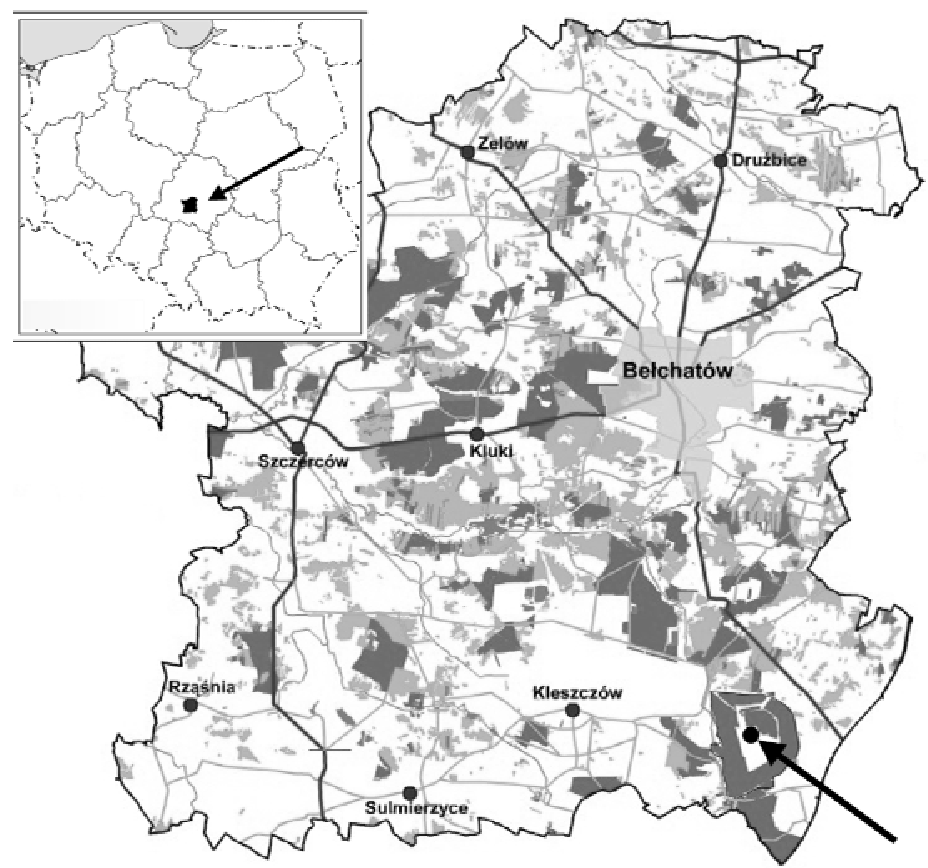

Fig. 1. Location of field experiment

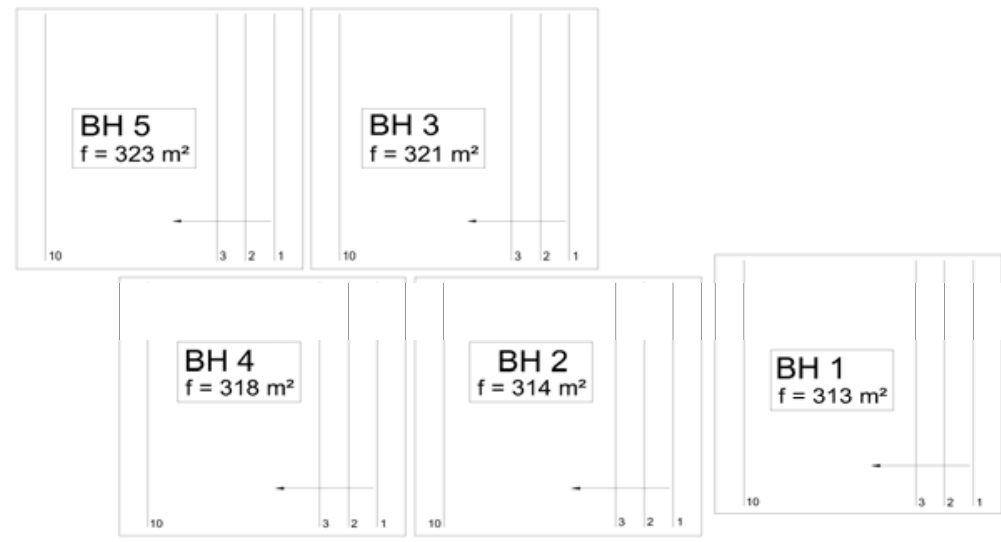

ROAD

Fig. 2. Set up of study plots used in the experiments; BH1 - control plot, BH2 - hydrogel applied surficially, BH3 - hydrogel applied under plants, BH4 - hydrogel used in a form of water gel applied directly on roots, BH5 - a mixture of hydrogel and fertilisers applied under plants 
Experimental doses were adopted according to the producer's recommendations. After planting the plant height above ground was measured. The measurements were repeated at the end of the vegetation period (November 2007) when dead plants were also calculated.

Habitat moisture was determined by atmospheric precipitation. Its amount measured in the year 2007 in the Wielun station (www.tutiempo.net) showed small deviations from measurements in other years and fell in the range of the country average precipitation in Poland (Fig. 3).

Experimental conditions did not allow for monitoring changes in soil moisture.

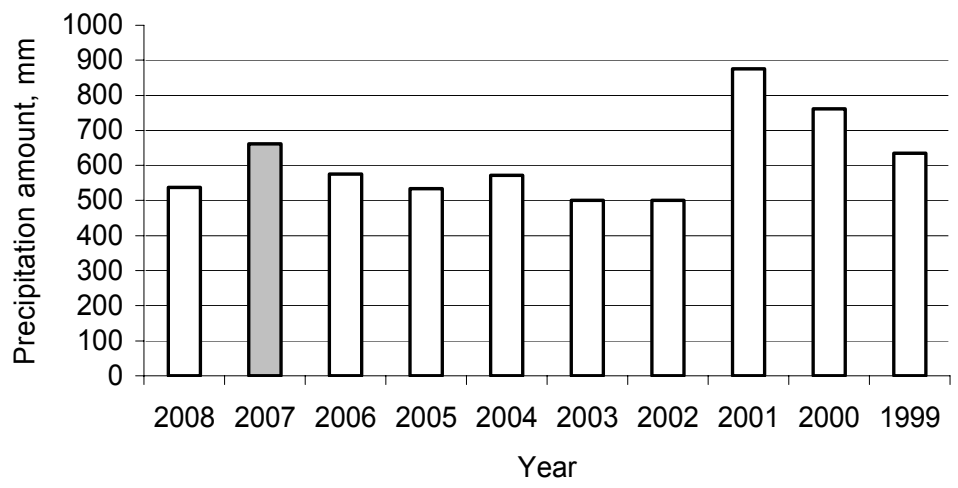

Fig. 3. The amount of atmospheric precipitation measured in the Wielun station $\left(51.21^{\circ} \mathrm{N}, 18.56^{\circ} \mathrm{E}\right)$

\section{RESULTS}

Obtained results of seedlings height, achieved increments and efficiency of planting for experimental variants after the first vegetation season are presented in Figs. 4-8. For better illustration, the results were grouped in height classes with height increments of $20 \mathrm{~mm}$.

Control plot devoid of any soil additives was planted with 292 seedlings of Scots pine of a height between 40 and $100 \mathrm{~mm}$ (mean height $82 \mathrm{~mm}$ ).

The seedlings that survived the first vegetation season had the height between 60 and $160 \mathrm{~mm}$. Mean growth increment of seedlings in this experimental variant was $31 \mathrm{~mm}$. Ninety percent of planted seedlings survived the first season. Small seedlings not higher than $100 \mathrm{~mm}$ dominated among those which dead before the end of the season.

294 seedlings of Scots pine were planted in experimental plot where soil conditioner was mixed with upper soil layer (Fig. 5). The height of most planted seedlings ranged between 40 and $100 \mathrm{~mm}$ (mean height $80 \mathrm{~mm}$ ). 

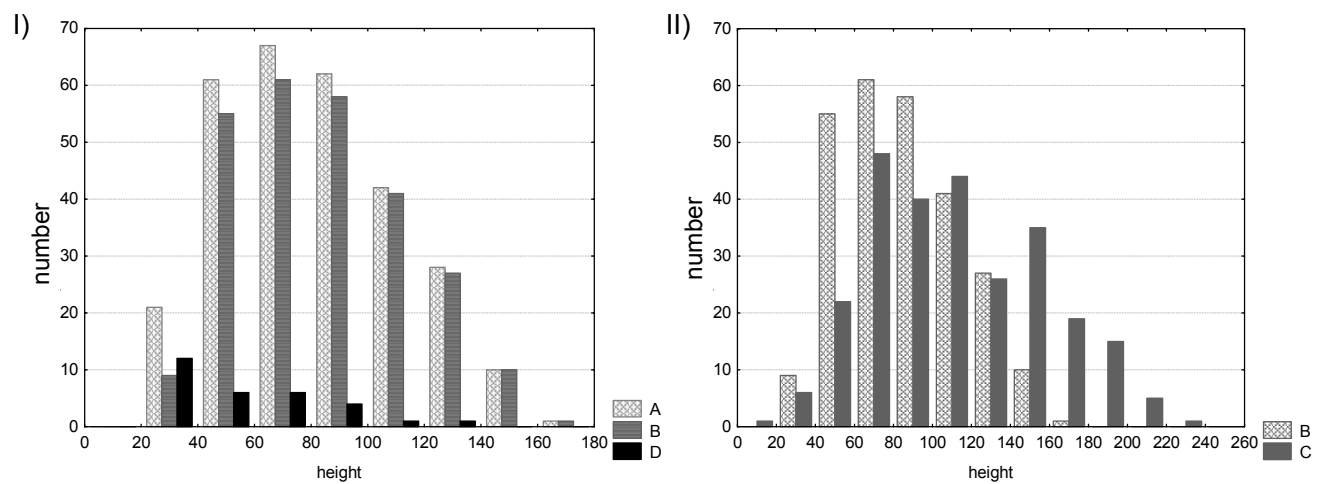

Fig. 4. The number of seedlings in height classes measured in the control plot BH1 I) - measurement after planting: A - all seedlings, B - seedlings that survived the first vegetation season, D - seedlings dead before the end of the vegetation season; II) - measurement after the first vegetation season: B height increments of plants after the first season, $\mathrm{C}$ - seedling heights after the first vegetation season
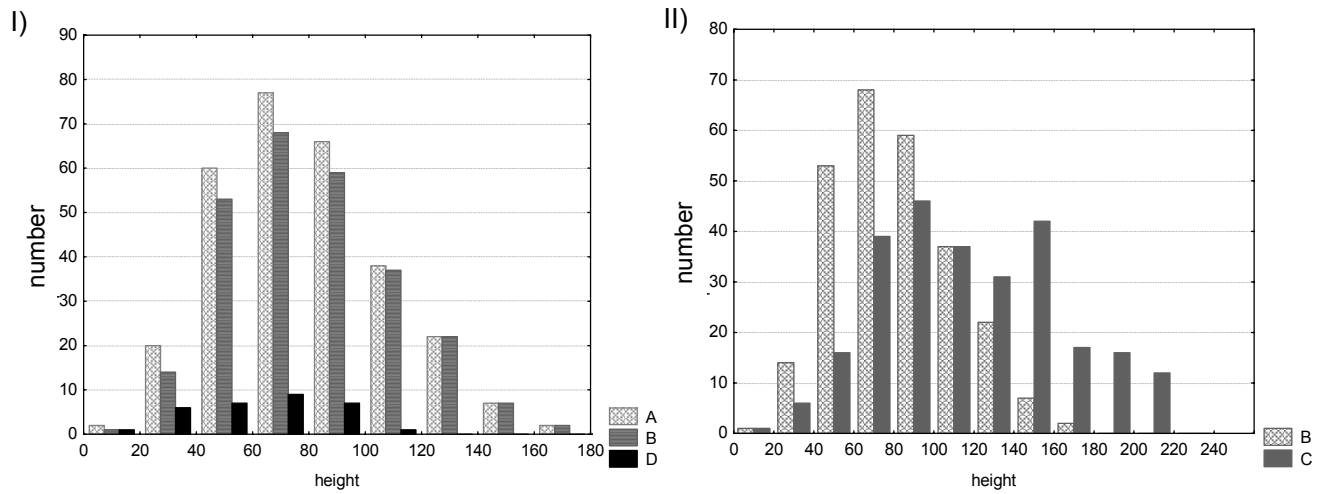

Fig. 5. The number of seedlings in height classes measured in the plot where hydrogel was mixed with upper soil layer (BH2): I) measurement after planting: A - all seedlings, B - seedlings that survived the first vegetation season, $\mathrm{D}$ - seedlings dead before the end of the vegetation season, II) measurement after the first vegetation season: B - height increments of plants after the first season, $\mathrm{C}$ - seedling heights after the first vegetation season

From among planted seedling $89 \%$ survived a year. At the end of the vegetation season remaining seedlings were dominated by those of a height between 60 and $160 \mathrm{~mm}$. Mean height of plants measured at the end of the season in this experimental variant was $117 \mathrm{~mm}$ while mean height increment was $40 \mathrm{~mm}$.

In the plot where hydrogel was applied under plants (Fig. 6) 306 seedlings were planted. Mean height of seedlings was $101 \mathrm{~mm}$.

Most numerous among planted seedlings were those of a height between 80 and $120 \mathrm{~mm}$ while the least numerous were plants of minimum $(20-40 \mathrm{~mm})$ and 

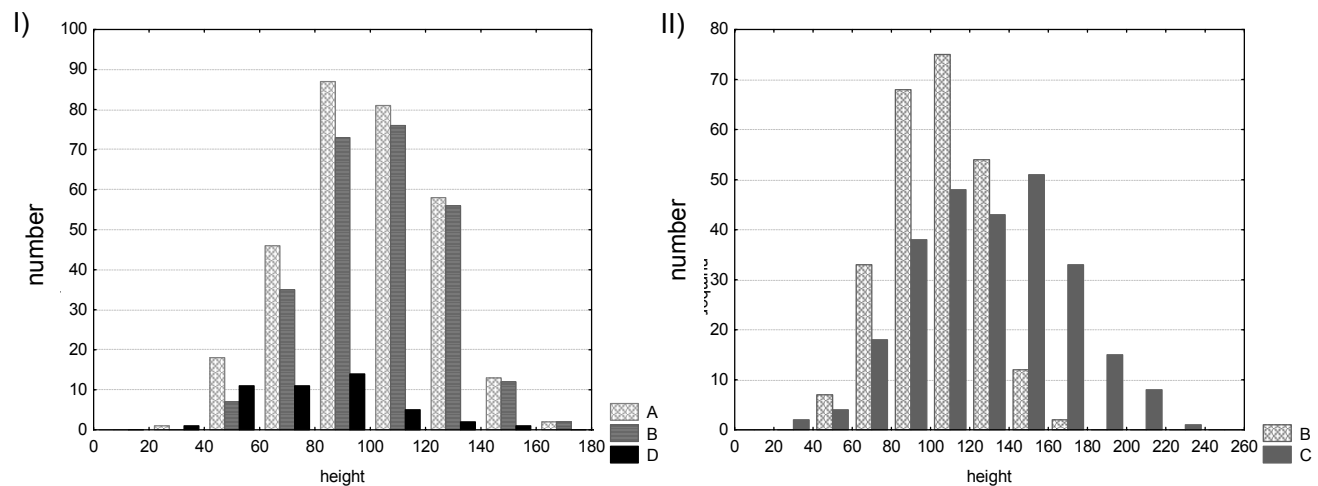

Fig. 6. The number of seedlings in height classes measured in the plot where hydrogel was applied under plants (BH3): I) - measurement after planting: A - all seedlings, B - seedlings that survived the first vegetation season, D - seedlings dead before the end of the vegetation season; II) - measurement after the first vegetation season: $\mathrm{B}$ - height increments of plants after the first season, $\mathrm{C}$ seedling heights after the first vegetation season

maximum (160-180 mm) height. Mean height increment of seedlings in this exerimental variant noted at the end of the vegetation season was $32 \mathrm{~mm}$. Eighty five percent of plants survived the first season. Among dead plants dominated those which did not attain $100 \mathrm{~mm}$ of height.

In experimental plot where soil conditioner was applied as aqueous gel onto plant roots 298 seedlings of Scots pine were planted (Fig. 7). Planted seedlings were dominated by plants whose height ranged between 60 and $120 \mathrm{~mm}$. Mean plant height was $93 \mathrm{~mm}$.
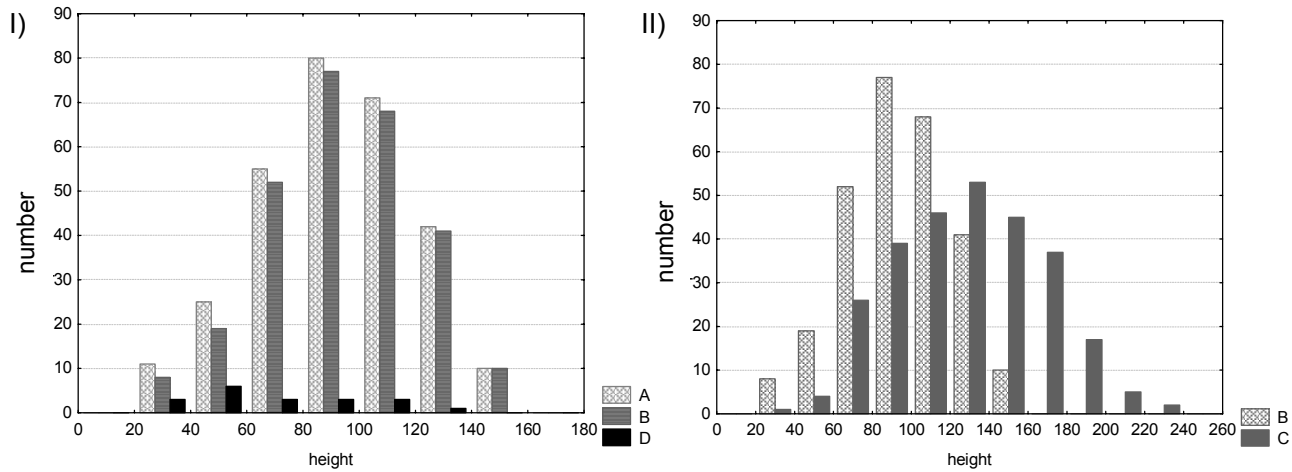

Fig. 7. The number of seedlings in height classes measured in the plot where soil conditioner was applied in a form of aqueous gel onto plant roots (BH3): I) - measurement after planting: A - all seedlings, $\mathrm{B}$ - seedlings that survived the first vegetation season, $\mathrm{D}$ - seedlings dead before the end of the vegetation season; II) - measurement after the first vegetation season: $\mathrm{B}$ - height increments of plants after the first season, $\mathrm{C}$ - seedling heights after the first vegetation season 
Mean height increment measured in this experimental variant at the end of the vegetation season was $38 \mathrm{~mm}$. The efficiency of planting was slightly above $93 \%$ for this experimental variant.

In experimental plot where hydrogel mixed with fertiliser was applied under plants 301 seedlings of Scots pine were planted (Fig. 8). Most numerous among planted seedlings were those of a height in the range 40-120 mm. Mean height of planted seedlings was $83 \mathrm{~mm}$.

Mean height of plants measured at the end of the vegetation season was 130 $\mathrm{mm}$ and mean height increment $-47 \mathrm{~mm}$. The efficiency of planting estimated after the first vegetation season was $72.5 \%$.

Results of performed experiments are summarised in Table 2.

I)

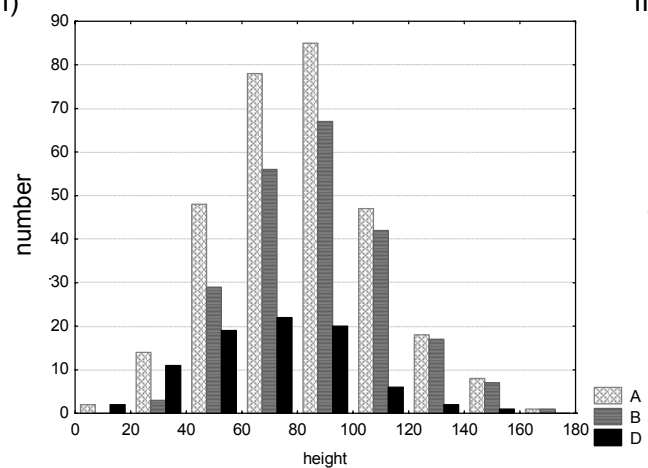

II)

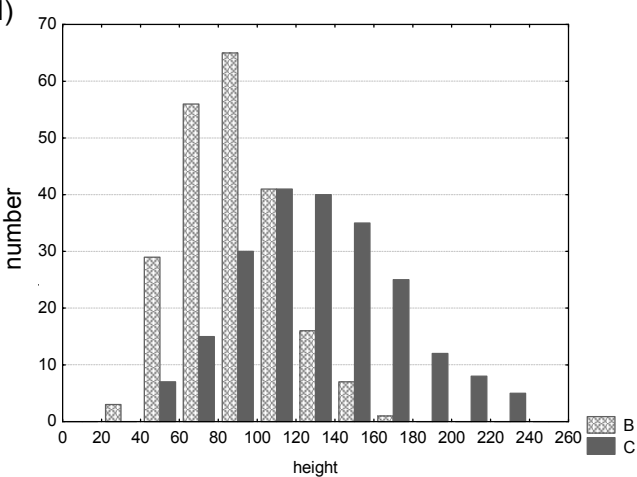

Fig. 8. The number of seedlings in height classes measured in the plot where hydrogel was mixed with fertiliser and applied under plants (BH3) I) - measurement after planting: A - all seedlings, $\mathrm{B}$ - seedlings that survived the first vegetation season, $\mathrm{D}$ - seedlings dead before the end of the vegetation season; II) - measurement after the first vegetation season: $\mathrm{B}$ - height increments of plants after the first season, $\mathrm{C}$ - seedling heights after the first vegetation season

Table 2. Set up of measurements aimed at estimating the efficiency and conditions of hydrogel application in afforestation of external waste heap in the Brown Coal Mine Bełchatów

\begin{tabular}{|c|c|c|c|c|c|}
\hline \multirow[b]{2}{*}{ Parameter } & \multicolumn{4}{|c|}{ Method of hydrogel application } & \multirow[b]{2}{*}{ 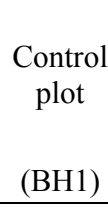 } \\
\hline & $\begin{array}{l}\text { on soil } \\
\text { surface } \\
(\mathrm{BH} 2)\end{array}$ & $\begin{array}{c}\text { under plants } \\
\qquad(\mathrm{BH} 3)\end{array}$ & $\begin{array}{c}\text { gel onto } \\
\text { roots } \\
(\mathrm{BH} 4)\end{array}$ & $\begin{array}{l}\text { under plants } \\
\text { with } \\
\text { fertiliser } \\
\text { (BH5) }\end{array}$ & \\
\hline Number of planted seedlings & 294 & 306 & 298 & 301 & 292 \\
\hline Mean height of seedling, $\mathrm{mm}$ & 80 & 101 & 93 & 83 & 82 \\
\hline Planting efficiency, $\%$ & 89.1 & 85.3 & 93.3 & 72.4 & 89.7 \\
\hline $\begin{array}{l}\text { Mean plant height after the } \\
1 \text { st vegetation season, } \mathrm{mm}\end{array}$ & 117 & 130 & 128 & 130 & 111 \\
\hline $\begin{array}{l}\text { Mean height increment after } \\
\text { the } 1 \text { st vegetation season, } \mathrm{mm}\end{array}$ & 40 & 32 & 38 & 47 & 31 \\
\hline
\end{tabular}




\section{SUMMARY}

Most studies on the use of polymer soil conditioners (hydrogels) for improving water and nutrient soil conditions pertained to field and garden crops. Their positive documented effect on habitat conditions is also utilised in forestry to restore the areas degraded by man. Presented results on the efficiency of hydrogel application in various variants after one vegetation season enable selection of the optimum method for given soil conditions and the amount of applied doses. Most seedlings that survived the first vegetation period (93.3\%) were noted in the plot where hydrogel was applied as aqueous solution on plant roots and the least $(72.4 \%)$ - for hydrogel applied in a mixture with fertilisers under seeded plants. Mean height increments after the first vegetation season were lowest in control plot $(31 \mathrm{~mm})$, similar $(38-40 \mathrm{~mm})$ in the variant with hydrogel application onto roots or surficially on soil and the largest $(47 \mathrm{~mm})$ when hydrogel was mixed with fertilisers and applied under plants. The highest survival of seedlings was obtained by covering plant roots with hydrogel without additives. This method gave also satisfactory height increments after the first vegetation season.

\section{REFERENCES}

1. Kahl L., Kluge R., Thomas S., Huttl R.F., Bradshaw A.D., 2000. Evaluation of an attempt to cultivate shrubs and trees on a heap of a potash mine. Landsc. Urban Plann., 51, 2-4: 109-112.

2. OSTRĘGA A., 2004. Sposoby zagospodarowania wyrobisk i terenów po eksploatacji złóż surowców węglanowych na przykładzie Krzemionek Podgórskich w Krakowie. Rozpr. dokt. (Management of mineral workings and areas after exploitation of carbonate minerals based on the example of Krzemionki Podgórskie in Cracow). PhDthesis. Kraków, AGH, Wydz. Górn. Geoinż.

3. Pierzgalski E., Ptach W., 1999. New techniques in subsurface irrigation. In: New approaches in irrigation, drainage and flood control management. Proc. ICID Intern. Symp. Bratislava, Slovak Republic. CD.

4. Rietveld W.J., 1976. Hydrophilic polymer rescues germination of Ponderosa Pine in seed spots. Tree Plant. Not., 27, 1: 18-19.

5. Silberbusch M., Adar E., De Malach Y., 1993a. Use of a hydrophilic polymer to improve water storage and availability to crops grown in sand dunes. I. Corn irrigated by trickling. Agricult. Water Manag., 23: 303-313.

6. Silberbusch M., AdAR E., De Malach Y., 1993b. Use of a hydrophilic polymer to improve water storage and availability to crops grown in sand dunes. 2nd. Cabbage irrigated by sprinkling with different water salinities. Agricult. Water Manag., 23: 315-327.

7. SZAFRAŃSKi C., STACHOWSKi P., KoZACZYK P., 2001. Wpływ warunków meteorologicznych na bilans wodny gleb wytworzonych z gruntów pogórniczych. W: Kompleksowe i szczegółowe problemy kształtowania środowiska. (The effect of meteorological conditions on water balance in soils made of post-mining grounds). Konf. nauk. Ustronie Morskie: 631-641.

8. SZAFRAŃSKi Cz., STACHOWSKI P., 1998. Zdolności retencyjne rekultywowanych rolniczo gruntów pogórniczych (Retention capaity of agriculturally restored post-mining grounds). Zesz. Probl. Post. Nauk Rol., 460: 457-466. 
9. SZAFRAŃSKI Cz., STACHOWSKI P., 1997. Zmiany zapasów wody w wierzchnich warstwach rekultywowanych rolniczo gruntów pogórniczych. (Changes in water resources of upper layers of agriculturally restored post-mining grounds). Rocz. AR Pozn., 294 Ser. Melior. Inż. Środ., 19, 2: 211-221.

10. Uberman R., OstręGA A., 2004. Sposoby rekultywacji i zagospodarowania zwałowisk nadkładu i składowisk odpadów górniczych. (Methods of restoration and management of overlayers and mine waste heaps). Górn. Odkrywk., 7-8: 80-87.

11. WiTT A., 2006. Przykłady rekultywacji oraz sukcesji naturalnej roślin w odkrywkowych wyrobiskach poeksploatacyjnych na terenie Dolnego Śląska. (Examples of restoration and natural plant succession in post-exploitation opencast pits). Wegiel Brunatny, 3/56: 30-34.

\section{STRESZCZENIE}

\section{Użycie hydrożelu na terenach poprzemysłowych przeznaczonych do zalesienia}

Słowa kluczowe: hydrożele, Pinus sylvestris, zalesienia

Na niektórych terenach przeznaczonych do zalesienia występuje brak wody i niedobór substancji pokarmowych. Jednym ze sposobów poprawy pojemności wodnej gleb jest wykorzystanie hydrożeli (polimerowych kondycjonerów glebowych). Prezentowane wyniki uzyskano, realizując na zalesianych powierzchniach składowiska kopalni węgla brunatnego w Bełchatowie doświadczenia z wykorzystaniem czterech metod aplikacji hydrożelu oraz doświadczenia kontrolnego. W przeprowadzonych eksperymentach wykorzystano hydrożel o handlowej nazwie Aquaterra bez domieszek oraz hydrożel z domieszką związków nawozowych (TerraVit), aplikowane do gleby o składzie granulometrycznym odpowiadającym piaskowi słabogliniastemu.

Na 5 poletkach doświadczalnych wysadzono od 292 do 306 jednorocznych sadzonek Pinus sylvestris L. o średniej wysokości 80-101 mm. Wpływ aplikacji hydrożelu na skuteczność zalesienia i wzrost sadzonek poddano analizie po pierwszym roku wegetacji. Najwięcej sadzonek, które przetrwały po I roku wegetacji (93,3\%), zaobserwowano na poletku, na którym hydrożel zastosowano w postaci pokrywającego korzenie roztworu wodnego, najmniej $(72,4 \%)$, gdy hydrożel z dodatkiem związków nawozowych zastosowano jako posypkę. Wyniki stosowania hydrożelu bez domieszek aplikowanego powierzchniowo $(89,1 \%)$ oraz jako podsypka $(85,3 \%)$ są porównywalne z uzyskanymi na poletku kontrolnym $(89,7 \%)$. Średnia wysokość przetrwałych sadzonek są porównywalne $(128-130 \mathrm{~mm})$ w przypadku stosowania nakorzeniowej aplikacji roztworu hydrożelu i obu metod podsypki (czysty hydrożel i hydrożel z posypką) w porównaniu $\mathrm{z}$ metodą powierzchniową $(117 \mathrm{~mm})$ i poletkiem kontrolnym, gdzie były najmniejsze (111 $\mathrm{mm}$ ). Średnie przyrosty pomierzone po roku od nasadzeń były najmniejsze na poletku kontrolnym $(31 \mathrm{~mm})$, porównywalne $(38-40 \mathrm{~mm}) \mathrm{z}$ uzyskanymi, gdy korzenie pokrywano roztworem i hydrożel stosowano powierzchniowo. Największe 
przyrosty $(47 \mathrm{~mm})$ uzyskano, stosując metodę podsypki hydrożelu z nawozami. Podsumowując: ze względu na przetrwalność sadzonek (udatność nasadzeń) za najlepszą metodę stosowania hydrożelu można przyjąć pokrywanie korzeni sadzonek jego roztworem. Metoda ta daje również zadowalające przyrosty sadzonek po pierwszym roku wegetacji.

Received 04.02.2009

Reviewers:

Dr. Piotr Leciejewski

Dr. Henryk Orzeszyna 